\section{AGING OF SOMATIC CELLS AS AN EXAMPLE OF STRUCTURAL CHANGE IN THE VITREOUS BODY WITH AGE}

\author{
Rasim .V. Hajiyev \\ Department of Ophthalmology , Azerbaijan State Advanced \\ Training Institute for Doctors named after A. Aliyev \\ (ASATID) , Baku, Azerbaijan
}

\begin{abstract}
:
Purpose: Based on the literature review and previous data, an analogy is drawn between the structure of the vitreous body and somatic cells. A comparison is made between changes in the vitreous body with age and the aging of somatic cells.

Methods: A review of the literature and hypotheses. Results(Hypothesis): With age, the amount of hyaluronic acid and microfibrils decreases and the volume of "empty space" increases, leading to the collapse of the vitreous body and a complete detachment. Let us imagine the vitreous body as a giant cell with a central nucleus. The cytoskeleton permeates the entire cell. The cytoskeleton provides a structural framework for the cell, serving as a framework that determines cell shape and the general organization of the cytoplasm. Importantly, the cytoskeleton is much less rigid and permanent than its name implies. We see the same thing in the microfibrils of the vitreous body.

Conclusion: With age, the density of the fibrillar structure of the vitreous body decreases. This structure is apparently, is an evolutionary intracellular formation that formed as a result of the apoptosis of the mesenchymal cells that form the primary vitreous body. An analogy is drawn between the loss of the density of fibrils of the vitreous body and the density of the cytoskeleton of asomatic cell. The loss of the cytoskeleton of a cell is a fatal process that cannot be stopped. The cytoskeleton cannot hold the nucleus in the center of the cell, which is why the nuclei of the older cells are not in the center, but are shifted to the periphery.
\end{abstract}

Keywords: Vitreous body, aging, vitreous, nucleus.

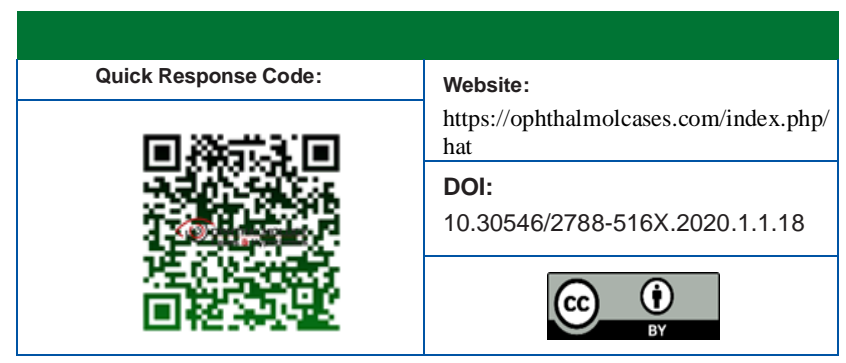

For many years, people have been trying to determine out the causes of aging, and there are so many theories. In 1908, physiologist Max Rubner discovered the relationship among the rate of metabolism, body size and life expectancy. In other words, long-lived animal species, on average, spend less calories per gram of body weight than smaller animals. The hypothesis of energy metabolism states that animals are born with a limited amount of some substance or potential energy and the faster they use it, the faster they die.1 Later, this theory evolved into the theory of the speed of life -the faster the rate of metabolism, the faster the biochemical activity and the faster the body will age.2

\section{Hypothesis}

\section{Common issues of ageing}

Some authors believe that the basis of the aging process is an increase in free radical reactions that occur continuously in all cells and tissues. It is believed that this is the main factor.3 Many authors believe that as apoptosis increases, it plays an important role in the aging process and how tumors occur in vivo. Apoptosis has been shown to enhance the elimination of damaged and dysfunctional cells, presumably caused by oxidative stress, in various cells.4 With age, there is also a decrease in the number of cells, including in the pigment epithelium and retina 5, and a reduction in the number of corneal endothelialcells.6The immunological theory of aging is widespread. It was first proposed and developed by Burnet and Walford.7 The main theory in this hypothesis is that the change with age, increases autoimmune reactions increase. It is believed that the development of autoimmune processes and other "diseases of age" occur as a result of a permanent decrease in T-cell activity. This activity is affected by the functional state of the thymus.8,9 Thus, the impaired immunoregulatory function is one of the immediate causes of an increase in the percentage of mortality among elderlypeople.10 An interesting hypothesis is that errors in DNA transcription lead to errors in proteins. These errors gradually accumulate and cause the cell to age and die. Errors in DNA repair also affect the accuracy of the flow of information in cells.11This common hypothesis failed the test of time. 


\section{Journal of Ophthalmology Cases $\mathcal{E}$ Hypotheses Volume 1, Number 1, 2020.18-22}

Studies conducted on flies have shown that with age, protein aggregates accumulate in muscle cells, which ultimately impairs their function.12 Recently, aging has been associated with the aging of each cell. It is believed that aging cells act as the main cause-and-effect agents of aging in mammals. 1 As cells age, they increase in size. Moreover, the nucleus increases to a lesser extent and changes its shape. Numerous invaginations of cellular and nuclear membranes are observed.13

Additional evidence exists that the nucleus is an integral part of the function of the interfacial cytoskeleton. This cytoskeleton is directly connected with the cytoplasm's cytoskeleton, and through intercellular space, the cytoskeleton of the cytoplasm is connected with the other cells.14 Recently, the search for one main cause of aging has been replaced by the idea of aging as an extremely complex, multifactorial process.15 Therefore, according to the authors, various theories of aging should be considered not as mutually exclusive but as complementary. In this manner, it was interesting to conduct ophthalmological studies on the structure of the vitreous body published by us earlier. These studies can also complement the wellknown notions about the aging of each organism as well as each cell.

\section{Aging in terms of changes in the structure of the vitreous body of the eye with age}

\section{Structure of the vitreous body}

The studies we conducted earlier suggested that the vitreous body can hypothetically be considered a giant living cell.16 Ophthalmologists can observe the structure of the vitreous body and its changes both pathologically and with respect to age. A dispute between histologists and ophthalmologists has existed for a long time. Do the collagen fibrils of the vitreous body truly exist?

Collagen tissue must be stained with a special dye-hematoxylin and eosin-but the collagen fibrils of the vitreous body do not stain. Ophthalmologists claimed that collagen fibrils they were visible in the light of a slit lamp. The dispute was resolved after these fibrils were attributed to a special type of collagen -type 4 collagen. Studies were conducted with experimental diabetes in rabbits.17 Histological studies of the retina were conducted. To determine whether retinal Müller cells are affected in diabetic retinopathy, the retina was stained with Amido Black-10B. This stain is effective at staining proteins. In parallel, it was discovered that this stain also stained fibrils of the vitreous body. This dye stains intracellular structures; therefore, it was suggested that the fibrils of the vitreous body may be intracellular formations. At a certain stage of eye development, the future cavity of the vitreous body is occupied by mesenchymal cells. Any of the cells can communicate with each other through the extracellular matrix. The fibrils of this matrix are designed so that they are in contact with and are a continuation of actin filaments and microtubules of intracellular formations.18 It was suggested that the membranes of the cells that filled the future cavity of the eyeball die off as a result of apoptosis, while the intracellular formations remain filamentous structures (cytoplasmic reticulum of all mesenchymal cells).

They represent the substrate of the vitreous body.19 Consequently, fibrils of the vitreous body can be thought of as the common cytoskeleton (cytoplasmic matrix) of embryonic cells, which previously had filled up the eye, cavity, where ophthalmologists

could observe them with the help of biomicroscopy. We discovered an interesting phenomenon of the phased nature of changes in the structure of the vitreous body during the "pendulum" test.20 This phenomenon is determined in people between the ages of 30 and 50, which is the age at which the dilution of the structure of the vitreous body occurs. The presence of this phenomenon indicates that fibrils of the vitreous body have a fractal structure.21 What is this structure? One of the main components of the vitreous body is hyaluronic acid. It is believed that it is located in the cells of the vitreous network.22 At the same time, the works of Agafonov 23 showed that there is a correlation between the disappearance of hyaluronic acid and the adhesion of collagen fibrils. In other words, hyaluronic acid is not located among the loops of the collagen network but is connected by small fibrils similar to a bottle brush. It is known that hyaluronic acid molecules carry a large negative charge. 24 This negative charge causes their mutual repulsion in anaquatic environment. The hyaluronic acid molecules are connected with collagen fibrils, and their mutual repulsion provides the necessary dispersion of the structure and the turgor of the vitreous body.

Therefore, the vitreous body is a complex fractal structure similar to multiple microfibrils ("tree branches") associated with hyaluronic acid molecules ("leaves on the branches").

The composition of the fluid surrounding these fibrils contains high antioxidant enzymeactivity. 25,26

\section{Changes in the structure of the vitreous body with age}

According to the literature and our data, the vitreous body liquefies with age.27 The vitreous body is homogeneous in structure for up to 30 years. Then, the density of the structure of the vitreous body decreases. Apparently, this is because of the loss of hyaluronic acid; that is, the "branches" are losing their "leaves". The remaining branches attract each other (since there are no negatively charged hyaluronic acid molecules). The smallest branches are glued together, twisted and take on various forms, which we see as "flying flies". This process can be enhanced in various eye diseases. Optically empty spaces appear in the vitreous region, and larger fibers are fused together, which can be seen biomicroscopically.

This observation is evidenced by data from other authors.28 The authors make the assumption that the reorganization of molecular networks of hyaluronic acid is taking place. The vitreous body is collapsing ; i.e., it is becoming completely detached. With age, the amount of hyaluronic acid and microfibrils decreases, and the volume of "empty space" increases, leading to the collapse of the 
vitreous body and a complete detachment.29 Let us imagine the vitreous body as a giant cell with a central nucleus. The cytoskeleton permeates the entire cell.

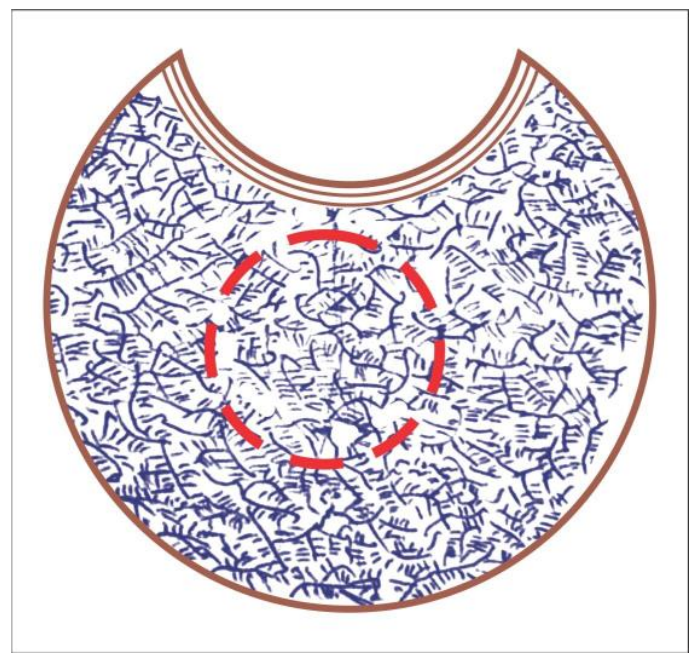

Figure.1. Scheme of vitreous body structure in a young person. The structure has the correct form of fractal geometry. The hypothetical nucleus is somewhat placed in the periphery.

The cytoskeleton provides a structural framework for the cell, serving as a scaffold that determines cell shape and the general organization of the cytoplasm. Importantly, the cytoskeleton is much less rigid and permanent than its name implies.30 We see the same thing in the microfibrils of the vitreous body.

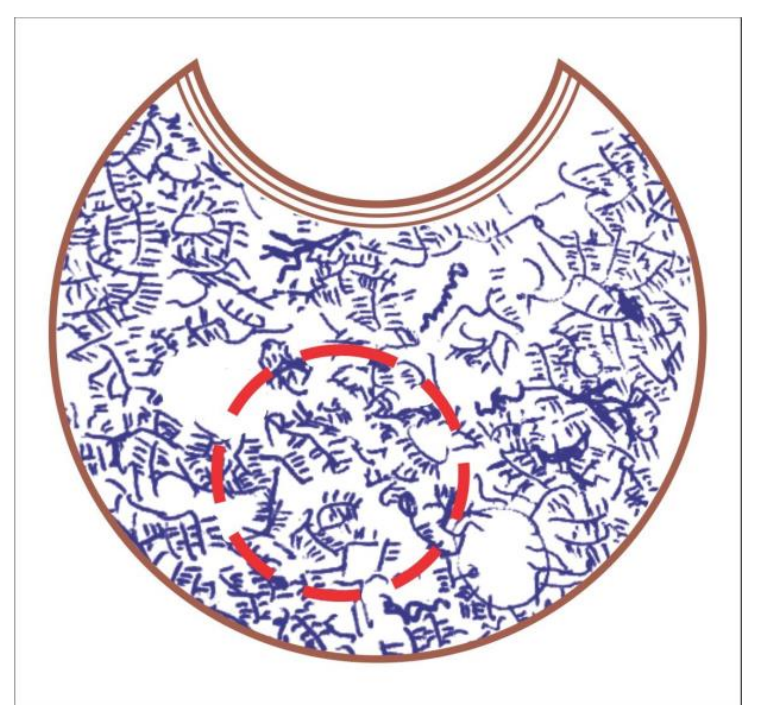

Figure 2. Scheme of the vitreous body structure in a middle-aged person. The hypothetical nucleus is somewhat placed in the periphery.

The nucleus is held by a dense skeleton of the endoplasmic matrix, which is composed of microfibrils in the vitreous body. If the microfibrils decrease in density as a result of the loss of hyaluronic acid and the microfibrils themselves, then the hypothetical "nucleus", by virtue of its "weight", may shift to the periphery and the outer membrane.

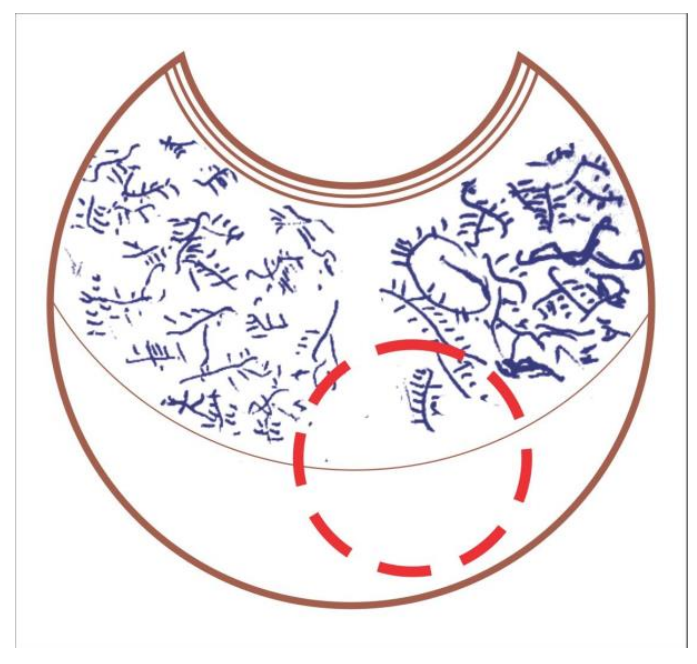

Figure. 3. Scheme of the vitreous body structure in an older man. The structure is discharged, and the fractal structure is absent. A complete detachment of the vitreous body is observed. The hypothetical nucleus is placed in the periphery. This process occurs in every cell of the body.

\section{Discussion}

With age, the density of the fibrillar structure of the vitreous body decreases. This structure is apparently an evolutionary intracellular formation that formed as a result of the apoptosis of the mesenchymal cells that form the primary vitreous body. An analogy is drawn between the loss of the density of fibrils of the vitreous body and the density of the cytoskeleton of a somatic cell. The loss of the cytoskeleton of a cell is a fatal process that cannot be stopped. The cytoskeleton cannot hold the nucleus in the center of the cell, which is why the nucleus of older cells is not located in the center but close to the membrane.

\section{Conflict of interests}

The author declares that there is no conflict of interests.

\section{Data availability statement}

The data that support the findings of this study are available from the corresponding author upon reasonable request.

Funding

None.

\section{Study association}

This study is not associated with any thesis or dissertation work 


\section{References}

1. Hayflick L. How and Why We Age. New York: Ballantine Books, 1994: 1-400.

2. Austad SN. Comparative aging and life histories in mammals. Exp Gerontol 1997; 32(1-2): 23- 38. DOI: 10.1016/s0531-5565(96)00059-9

3. Harman D. The aging process. Proc Natl Acad Sci U S A 1981; 78(11): (1981): 7123-7128. doi: 10.1073/pnas.78.11.7124

4. Higami Y., Shimokawa I. Apoptosis in the aging process. Cell Tissue Res 2000; 301(1): 125- 132. DOI: 10.1007/s004419900156

5. Ermilov VV. Turenkov IN, Smirnov AV. et al. Morphology 2016; 3; 80-80. (in Russian). https://www.rucont.ru/efd/599428

6. Galgauskas S., et al. Age-related changes in corneal thickness and endothelial characteristics.Clin Interv Aging 2013;8: 1445-50. doi: 10.2147/CIA.S51693

7. Walford RL., Smith GS, Meredith PJ, Cheney KE Immunogenetics of aging. In: Schneider editor. The genetics of aging. New York: Plenum Press,1978.

8. Kay MM. An overview of immine aging. Mech.Ageing Dev 1979; 9(1): 39-59. doi.org/10.1016/00476374(79)90119-2

9. Hirokawa K, Utsuyama M, Goto H, Kuramoto K. Differential rate of age-related decline in immune functions in genetically defined mice with different tumor incidence life span. Gerontology 1984; 30(4): 223233. DOI: $10.1159 / 000212636$

10. Yunis EJ, Lane MA. Cellular immunity in aging. J. Invest. Dermatol 1979; 73(1): 24-28.

11. Orgel LE. Ageing of clones of mammalian cells. Nature 1973; 243.5408 (1973): 441-445.

12. Demontis, F., Perrimon, N. FOXO/4E-BP signaling in Drosophila muscles regulates organism- wide proteostasis during aging. Cell 2010; 143(5): 813-825. doi: 10.1016/j.cell.2010.10.007

13. Pienta KJ, Getzenberg RH, Coffey DS. Characterization of nuclear morphology and nuclear matrices in ageing human fibroblasts. Mech Ageing Dev 1992; 62(1): 13-24. DOI: 10.1016/0047-6374(92)90140-9

14. Burke B, Stewart CL. Functional architecture of the cell's nucleus in development, aging, and disease. Curr Top Dev Biol 2014;109:1-52. doi: 10.1016/B978-0-12-3979209.00006-8

15. Tosato M, Zamboni v, Ferrini A, Cesari M. The aging process and potential interventions to extend life expectancy. Clin Interv Aging 2007; 2(3): 401-412.

16. Hajiyev RV. O patogeneze diabeticheskoy retinopatii i tromboz sentralnoy veni setchatki [On the pathogenesis of diabetic retinopathy and Central retinal vein occlusion]. Baku: Poligraphic production, 2011:1-71. (in Russian).
17. Hajiyev RV. Vzaimodeystviye glialnix kletok setchatki s kollagenovim matriksom steklovidnogo tela [The interaction of glial cells of the retina with the collagen matrix of the vitreous body] in actual problem oftalmologii]. Baku: Elm, 1998: 329-330. (in Russian).

18. Bruce Alberts et al. Essential biology. New York: Garland Science, 2010. Print.

19. Hajiyev RV. Metodika osenki sostoyaniya biomikroskopicheskoy strukturi stekolvidnogo tela po dannim pokazateley "mayatnikovoq probi. Metidicheskaya rekomendasiya [The technique of biomicroscopic assessment of the structure of the vitreous body according to the indicators of the "pendulum test". Methodical recommendation]. Baku: Elm, 1997: 1-16.

20. Hajiyev RV. O biomikroskopicheskoy structure steklovidnogo tela [On the biomicroscopic structure of the vitreous body]. Vesnkik ophthalmologii 1992; 5: 378 Depo 5. (in russian).

21. Hajiyev RV. Izmeneniye microfibril steklovidnogo tela pri dvizhenii glaz [Change microfibrils of the vitreous when eye movement]. In actual problem oftalmologii. Baku: Elm, 2003: 1-320.

22. Balazs EA. Molecular morphology of the vitreous body. In Smelser G.K. (ed) The structure of the eye. New York: Academic Press, 1961: 293-310.

23. Agafonov VA. Ultrastrukturniye osobennosti patologii steklovidnogo tela. Eksperimentalniye issledovaniya $\mathrm{v}$ oftalmologii [Ultrastructural features of the pathology of the vitreous body. Experimental research in ophthalmology]. In: Collection of scientific works of the Moscow Scientific Research Institute of Microsurgery. Moscow: 1986: 112-116. (in Russian).

24. Policard A. et al. Electron microscopic studies on alveolar cells from mammals Proc.Ist European Regional Conf.Electr.Micr. Stockholm: Almqvist \& Wiksell, 1956: 244.

25. Aliyeva ZA, Hajiyev RV9 et al. "Soderzhaniye selena i aktivnost glutationperoksidaznix fermentov $\mathrm{v}$ tkanyax glaza [The content of selenium and glutathione peroxidase activity of enzymes in the tissues of the human eye in diabetes]". Vestnik oftalmologii 1985;3: 21-24.

26. Aliyeva ZA, Hajiyev RV, Sultanov MY, Huseynov TM, Yusifov EY. O vozmozhnoy roli antioksidantnoy sestemi steklovidnogo tela $\mathrm{v}$ zaderzhke rasvitiya diabeticheskoy retinopatii [On the possible role of the antioxidant system of the vitreous body in the delay in the development of diabetic retinopathy]. Oftalmologicheskiy zhurnal 1985; 3: 26-31. 
27. Hajiyev RV. Biomikroskopicheskiye izmeneniya steklovidnogo tela $\mathrm{v}$ zavisimosti ot vosrasta. Gerongologicheskiye paraleli [Biomicroscopic changes of vitreous body depending on age, gerontological Parallels]. In actual problem oftalmologii. Baku: Elm, 2008: 220-223.

28. Sebag J. Age-related changes in human vitreous structure. Graefes Arch Clin Exp Ophthalmol 1987; 225(2): 89-93.

https://link.springer.com/article/10.1007/BF02160337

29. Hajiyev RV. Posterior vitreous detachment in pathogenesis of diabetic retinopathy. Ophthalmosurgery1992; 2:49-52

30. Cooper GM. The Cell: A Molecular Approach. 2nd edition. Sunderland (MA): Sinauer Associates, 2000 